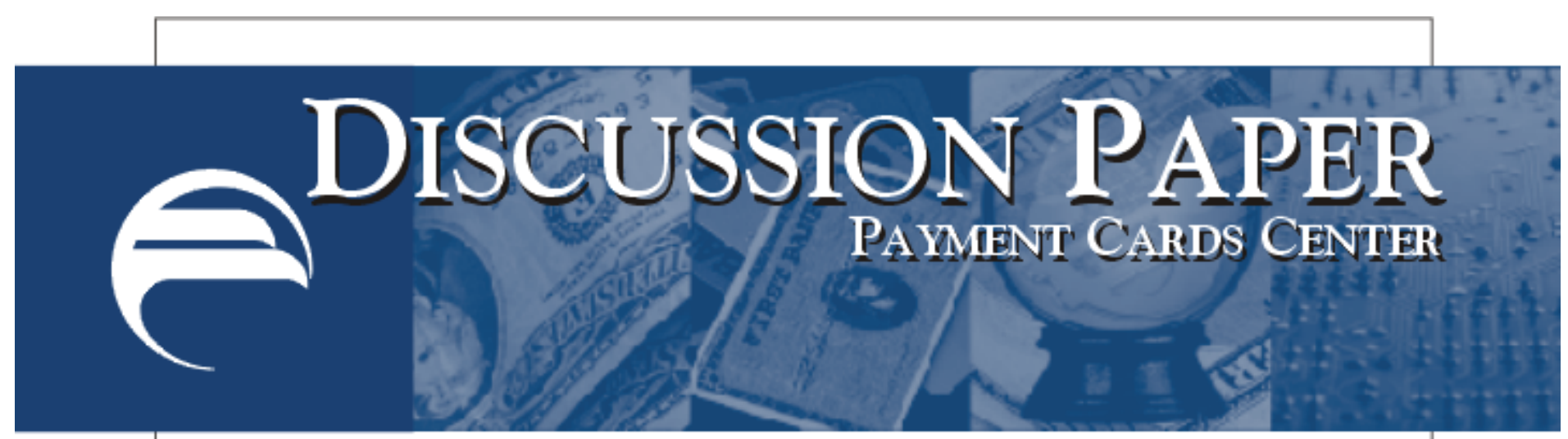

\title{
Consumer Bankruptcy: How Unsecured Lenders Fare
}

\author{
Mark Furletti
}

November 2003

Summary: On September 8, 2003, the Payment Cards Center of the Federal Reserve Bank of Philadelphia hosted a workshop on consumer bankruptcy and its effect on unsecured lenders. Professor Melissa Jacoby of Temple University's School of Law led the workshop. A leading bankruptcy scholar, Jacoby described the current bankruptcy system and the potential impact of Chapter 7 reforms on the rights of unsecured creditors. This paper summarizes Jacoby's presentation and the ensuing discussion. It offers a brief overview of consumer bankruptcy and the rights of unsecured creditors that lend money to individuals who ultimately file for bankruptcy. It also discusses the proposed amendments to the bankruptcy code being debated in Congress. Finally, the paper concludes with Jacoby's assessment of how unsecured lenders, such as credit card issuers, would likely be treated in the proposed system.

* The views expressed here are not necessarily those of this Reserve Bank or of the Federal Reserve System.

\section{Federal Reserve Bank of Philadelphia}




\section{Introduction}

Over 1.6 million non-business bankruptcy cases were filed in federal court in the 12month period ending June 2003. ${ }^{1}$ This represented a 10 percent increase over the same period in $2002^{2}$ and a 100 percent increase over the same period in $1995 .^{3}$ The impact of bankruptcy on credit card issuers is significant. ${ }^{4}$ In 2002, credit card issuers charged off a record $\$ 60$ billion. ${ }^{5}$ Almost one-third of these chargeoffs (approximately $\$ 18$ billion) were due to cardholder bankruptcy. ${ }^{6}$ A dramatic increase in bankruptcies and an attendant increase in chargeoffs due to bankruptcies have had credit card issuers lobbying for reform for several years.

The treatment of card issuers in the current bankruptcy system and the bankruptcy reforms being considered by Congress were topics of a Payment Cards Center workshop held on September 8, 2003. The Center invited bankruptcy expert Melissa Jacoby of Temple University's School of Law to lead the workshop. This paper, based on Jacoby's presentation and additional Center research, offers an overview of consumer bankruptcy laws and their effect on unsecured creditors. The paper also considers the proposed amendments to the bankruptcy code currently being debated in Congress. The paper concludes with Jacoby's assessment of how unsecured lenders, such as credit card issuers, would likely be treated under the proposed system.

\section{Consumer Bankruptcy}

The United States Supreme Court, in a 1915 opinion, explained the purpose of bankruptcy as follows:

\footnotetext{
${ }^{1}$ Bankruptcy Cases Continue to Break Federal Court Caseload Records, Administrative Office of the U.S. Courts, Aug. 18, 2003 [hereinafter Caseload Records], at http://www.uscourts.gov/Press_Releases/603b.pdf.

${ }^{2} I d$.

${ }^{3}$ Bankruptcy Filings Down in Calendar Year 2000, Administrative Office of the U.S. Courts, Feb. 23, 2001, at http://www.uscourts.gov/Press_Releases/press_02232001.pdf.

${ }^{4}$ It is interesting to note that the credit card debt owed by one-third of bankruptcy filers is equivalent to an entire year's worth of their salary. Michelle Conlin, Middle Class and Maxed Out, Bus. WK., Sept. 15, 2003, at 22.

${ }^{5}$ Bankruptcy Debt Recovery- Part 2, NILSON REP., Feb. 2003, at 1.

${ }^{6} \mathrm{Id}$. at 6.
} 
...to convert the assets of the bankrupt into cash for distribution among creditors, and then to relieve the honest debtor from the weight of oppressive indebtedness, and permit him to start afresh...

Overall, the bankruptcy system allows consumers who are unable to meet their financial obligations to "start afresh" in a manner that is fair and equitable to their creditors. Those who file for bankruptcy can emerge with less debt and more favorable repayment terms on the debt that they retain. Filers also benefit from a court-enforced "stay," an order that temporarily prevents creditors from making any efforts to collect the debts the filer has included in the bankruptcy. ${ }^{8}$

Consumers basically have two filing options: Chapter 7 (often referred to as a "liquidation") and Chapter 13 (often referred to as a "reorganization"). Regardless of which chapter consumers choose, the end result is the same - they do not have personal liability for many of their debt obligations at the conclusion of the process. In bankruptcy parlance, these debt obligations are "discharged." In Chapter 7, the discharge of debt occurs soon after the filing, while in Chapter 13 the discharge usually does not occur until the completion of a three- to fiveyear repayment plan. In theory, Jacoby explained, Chapter 7 debtors essentially "buy" a discharge with the assets they currently hold. With certain exceptions, debtors' assets are handed over to a court-appointed trustee who liquidates them and divides the resulting proceeds among creditors according to bankruptcy code provisions. Any unsecured debt that remains is uncollectible. In Chapter 13, Jacoby explained, debtors "put their discharge on layaway" and essentially buy the discharge with future income. The debtor proposes a three- to five-year plan during which secured loans, priority debts, and, to the extent there is disposable income left over, some portion of the debtor's unsecured loans are repaid. At the end of the plan, the debtor's remaining

\footnotetext{
${ }^{7}$ Williams v. U.S. Fidelity \& Guaranty Co., 236 U.S. 549, 554-55 (1915).

${ }^{8}$ DOUGlas G. BAIRD, ElEMENTS OF BANKRUPTCY 38 (3d ed. 2001).
} 
unsecured debts are discharged. The next two sections briefly describe Chapters 7 and 13 and highlight how unsecured creditors are treated under these two regimes.

\section{Chapter 7}

Almost 70 percent of the 1.6 million bankruptcies filed between July 1, 2002, and June 30, 2003, were filed under Chapter 7. ${ }^{9}$ Those who file for Chapter 7 essentially trade all of their current assets (with some exceptions) for freedom from the obligations associated with their past debts. In this way, Chapter 7 is mostly attractive to debtors for whom the value of their debts vastly exceeds the value of their assets. ${ }^{10}$ These typically include debtors who do not own a home and who have large amounts of unsecured debt. ${ }^{11}$ According to the Department of Justice, 96 percent of the Chapter 7 bankruptcies filed in the 12-month period ending in June 2002 were "no asset filings." 12 This means that after allowing debtors to retain assets considered necessary for them to remain self-sufficient (e.g., future income, clothes, and some furniture and household items) and excluding assets fully encumbered by security interests, very few Chapter 7 filers had any remaining valuables. Chapter 7 filers with assets above and beyond those needed for selfsufficiency are required to relinquish them to a trustee for liquidation. The proceeds of this liquidation are generally divided among general unsecured creditors on a pro rata basis after satisfying secured claims, priority claims, or both.

Jacoby explained that unsecured creditors face three obstacles that limit the possibility of recovering anything from those who file Chapter 7: generous state exemptions, unfavorable rules applicable to the distribution of proceeds, and deficient asset verification procedures.

\footnotetext{
${ }^{9}$ Caseload Records, supra note 1.

${ }^{10}$ BAIRD, supra note 8, at 38 .

${ }^{11}$ Ed Flynn et al., Bankruptcy by the Numbers - A Tale of Two Chapters, 21 AM. BANKR. INST. J. No. 7 (2002), at http://www.usdoj.gov/ust/press/articles/abi82002.htm.

${ }^{12}$ Ed Flynn et al., Bankruptcy by the Numbers - Chapter 7 Asset Cases, 21 AM. BANKR. InST. J. No. 9

(2003), at http://www.usdoj.gov/ust/press/articles/abi122002.htm.
} 
First, although a court-appointed trustee has the power to sell the filer's assets to repay creditors, state and federal laws exclude certain assets from sale by the trustee. ${ }^{13}$ As explained above, the excluded or "exempt" assets are purposefully placed beyond the reach of creditors so that the debtor can remain self-sufficient. ${ }^{14}$ Jacoby explained that depending on the laws of their state, debtors may opt for the state or federal exemption - generally choosing the more generous of the two if they are in the minority of states that permit such a choice. Federal law exempts items such as retirement plans, $\$ 2,775$ of motor vehicle equity, $\$ 17,425$ of home equity, and $\$ 9,300$ of household goods and furnishings. ${ }^{15}$ State exemptions vary significantly. For example, Texas offers very generous exemptions, allowing debtors to keep all of their home equity ${ }^{16}$ and $\$ 60,000$ of personal property. ${ }^{17}$ Pennsylvania, a far less generous state, does not exempt any home equity but allows debtors to exempt only some specific personal items (e.g., bible, sewing machine, and wearing apparel). ${ }^{18}$ The extent to which a debtor may exempt assets disproportionately affects unsecured creditors. Bankruptcy generally does not remove a creditor's security interest in an asset. After the court-enforced stay is over, a secured creditor can always seize its asset if the debtor does not make the required payments. Unsecured creditors, however, are left with little or no recourse after the bankruptcy discharge unless the debtor, court, and creditor agree otherwise. They are entitled only to a pro rata share of the proceeds that remain after the non-exempt assets are sold. Ultimately, the more generous the exemptions, the less available for distribution to unsecured creditors.

\footnotetext{
${ }^{13}$ For an economic analysis of the wide disparities between different states' property exemptions that also are applicable in bankruptcy, see Ronel Elul \& Narayanan Subramanian, Forum Shopping and Personal Bankruptcy, 21 J. OF FIN. SERVICES RES. 234 (2002).

${ }^{14}$ BAIRD, supra note 8 , at 46.

1511 U.S.C. $\S 522$ (2003). Please note, these exemption amounts adjust with inflation.

${ }^{16}$ See TEX. CONST. art. XVI $\S 50(\mathrm{a})$.

${ }^{17}$ TEX. Prop. Code ANN. $§ 42.001$ (Vernon 2003).

1842 PA. CONS. STAT. $§ 8124$ (2003). Although Pennsylvania's exemptions are less generous, the state recognizes tenancy by the entirety, a form of property ownership between a husband and wife. This form of ownership, in some instances, can help filers keep jointly owned real estate from being sold by the bankruptcy trustee.
} 
Second, recovery prospects of unsecured lenders are negatively affected by repayment prioritizations and creditor preferences set forth in the bankruptcy code. Unsecured creditors are last among those who need to be paid out of the proceeds of the sale of non-exempt assets. Secured lenders, bankruptcy trustees, and attorneys have priority for the full amount of their claims over unsecured lenders. The bankruptcy code also subordinates unsecured debt, such as credit card debt, to unsecured debt held by "priority creditors." Debt owed to priority creditors is considered non-dischargeable and includes student loans, court fees, criminal fines, child support, and most federal, state, and local taxes. ${ }^{19}$

Finally, Jacoby noted that unsecured creditor recoveries can also be negatively impacted by potentially sloppy asset verification procedures. It is the responsibility of the bankruptcy trustee to verify the asset information the debtor provides in the filing. Ideally, trustees would confirm the self-reported information by examining bank statements, home appraisals, and prior income tax filings. In practice, however, trustees generally have spent little verifying information. Jacoby explained that trustees, who are paid just $\$ 75$ per case by the court, are simply not compensated in a way that would encourage such thoroughness. Undetected inaccuracies in a debtor's filing may shelter assets that should otherwise be liquidated and distributed to unsecured creditors. In an effort to combat abuses of the bankruptcy system, the U.S. Trustee Program launched a civil enforcement initiative in October 2001. This initiatives aims to crack down on those that make false representations in their bankruptcy filings. ${ }^{20}$

Given the systematic challenges that unsecured creditors face, it is not surprising that, of the $\$ 1.5$ billion disbursed to Chapter 7 creditors in fiscal year 2001, unsecured creditors received

\footnotetext{
${ }^{19}$ In 2002, bankruptcy reform efforts were actually derailed by disagreements over what kinds of debt should be deemed non-dischargeable. At the center of the controversy was a provision that would have made the financial penalties imposed by courts on abortion clinic protestors non-dischargeable. See Tom Hamburger \& Shailagh Murray, Bankruptcy Bill Surprisingly Fails Over Obscure Abortion Provision, WALL ST. J., Nov. 15, 2002, at A1.

${ }^{20}$ U.S. Trustee Program Launches Bankruptcy Civil Enforcement Initiative, Executive Office for U.S. Trustees, Oct. 30, 2001, at http://www.usdoj.gov/ust/press/pr20011030.htm.
} 
about $\$ 350$ million, or one-quarter, of this payout. ${ }^{21}$ Although Chapter 7 bankruptcies often result in a complete loss for card issuers, firms that specialize in finding errors and fraud in bankruptcy petitions will sometimes purchase Chapter 7 chargeoffs for $\$ 0.01$ per $\$ 100$ of debt. ${ }^{22}$ In contrast, non-bankruptcy credit card chargeoffs can fetch as much as $\$ 5$ per $\$ 100$ of debt. $^{23}$

Generally, the best an unsecured creditor can hope for in a Chapter 7 bankruptcy, Jacoby explained, is debt reaffirmation. Before his or her debts are formally discharged, a debtor can ask the court to allow one or more debts to be reaffirmed or excluded from the discharge. By "reaffirming" his or her responsibility for a particular debt (e.g., a car loan), the debtor is able to keep possession of the asset that underlies it (e.g., a car). Jacoby indicated that 20 percent to 25 percent of Chapter 7 filers reaffirm at least one debt. The majority of reaffirmed debt, she explained, is unsecured or minimally secured. Given the importance of having a credit card to be able to make hotel reservations or put down temporary security deposits on goods, it may be in a filer's interest to reaffirm at least one of his or her credit card debts.

\section{Chapter 13}

Approximately 30 percent of the consumer bankruptcies filed in the 12 -month period ending in June 2003 were filed under Chapter 13. Unlike Chapter 7 debtors, who are required to hand over all of their non-exempt unencumbered assets (including any non-exempted home equity), Chapter 13 debtors can keep all of their property and possessions. Instead of paying creditors with proceeds from a sale of their assets, Chapter 13 debtors pledge to pay creditors for a period of three to five years with any future income above that necessary to cover living expenses (i.e., any disposable income). To accomplish this, the debtor and bankruptcy court work out a monthly payment plan that requires the debtor to send monthly payments to a bankruptcy trustee for creditor distribution. At the end of the three- to five-year plan, any unsecured debt that remains is discharged.

\footnotetext{
${ }^{21}$ Flynn, supra note 11.

${ }^{22}$ Bankruptcy Debt Recovery-Part 2, supra note 5, at 6.
} 
Chapter 13 is especially attractive to debtors facing foreclosure or who have non-exempt home equity (i.e., more equity than allowed by state or federal law) because of special provisions that help stave off foreclosure. ${ }^{24}$ Although the bankruptcy code does not allow a debtor to change any of the terms of his or her mortgage (e.g., interest rate, length of loan, fee structure), it does allow the debtor to "cure" a default. In exchange for satisfying past due mortgage payments, Chapter 13 enables a debtor to have his or her mortgage "cured" or reinstated to its original terms. ${ }^{25}$ Once the Chapter 13 debtor cures his or her mortgage, it is as if the default never occurred. These home protections, as well as the ability to make debtor-friendly modifications to car loans, make Chapter 13 an attractive option for those who have property they want to keep.

Given the future income expectations and homeownership desires of those who are attracted to Chapter 13, it is not surprising that this chapter returns more money to secured and unsecured creditors. ${ }^{26}$ Jacoby indicated, however, that Chapter 13's provisions place general unsecured creditors at a distinct disadvantage.

As in Chapter 7, unsecured creditors have the lowest priority. Secured lenders, lawyers, and priority creditors (e.g., those owed child support, taxes, alimony), take priority over unsecured creditors in two ways. First, their claims are the first to be subtracted from the debtor's total disposable income for the three- to five-year period. What disposable income that remains is divided among unsecured creditors on a pro rata basis. Second, most debtor's plans defer payment of unsecured creditors until later in the plan period. The debtor prefers to direct the early portion of payments to those creditors that must be paid in full (i.e., secured creditors). An unsecured creditor may have to wait years before receiving any money, reducing the net present value of their repayment.

\footnotetext{
${ }^{23}$ Credit Card Debt Sales, NiLSON ReP., July 2003, at 6.

${ }^{24}$ BAIRD, supra note 8 , at 58.

25 Id.

${ }^{26}$ For example, in fiscal year 2001, Chapter 13 disbursed a total of $\$ 3.6$ billion compared to $\$ 1.5$ billion disbursed under Chapter 7. Unsecured creditors received $\$ 805$ million in Chapter 13 disbursements and
} 
As in Chapter 7, trustees take priority over unsecured lenders. In Chapter 13, however, a trustee's duties are more complex. Among other things, a Chapter 13 trustee must oversee the debtor's three- to five-year repayment plan. For their work, Jacoby explained, trustees sometimes receive as much as 10 percent of the disbursements, although the percentage varies by bankruptcy court district. In fiscal year 2001, trustees received approximately $\$ 380$ million, almost half as much as was returned to unsecured creditors ( $\$ 800$ million) ${ }^{27}$

Since unsecured creditors are the last to be repaid, they are incommensurately disadvantaged when a debtor has low non-disposable income. The code allows debtors to retain income for "necessary expenses." Jacoby explained, however, that the meaning of "necessary" can vary greatly. Trustees, creditors, and debtors could find themselves entangled in litigation over whether private-school tuition payments, children's braces, airfare for trips to see relatives, and other such expenditures are "necessary" expenses. The extent to which debtors are able to increase the level of these expenses reduces the amount available to support repayment of unsecured creditors.

One of the greatest risks for unsecured creditors in Chapter 13 involves plan completion. Despite the effort (and often the $\$ 1,000$ to $\$ 1,500$ in fees for an attorney) ${ }^{28}$ that goes into filing a Chapter 13 bankruptcy, Jacoby asserted that only one-third of filers actually complete their plans. $^{29}$ This low completion rate disproportionately impacts unsecured lenders because, as explained above, they are not usually scheduled to receive any distributions until the latter years of the program. Debtors who do not complete their plans, however, generally do not receive a discharge, clearing the way for unsecured creditors to resume collection efforts if they so choose.

$\$ 357$ million in Chapter 7 disbursements. Secured creditors received \$2.1 billion in Chapter 13 disbursements and \$451 million in Chapter 7 disbursements. Flynn, supra note 11.

${ }^{27} I d$.

${ }^{28}$ Amy Borrus, Personal Bankruptcy: Beware the Next Chapter Reforms Will Make It Harder to File Successfully, Bus. WK., Sept. 30, 2002, at 112.

${ }^{29}$ She indicated that this proportion has remained stable over time, although it varies by state. 
Overall, Chapter 13 disbursements accounted for 70 percent of the money returned to unsecured creditors through the bankruptcy system. ${ }^{30}$ This, however, does not take into account sums paid to creditors outside and after bankruptcy.

\section{Bankruptcy Reform Legislation}

After describing the current provisions of Chapters 7 and 13, Jacoby discussed the reform legislation passed by the House of Representatives last spring. ${ }^{31}$ According to the Judiciary Committee's report, the purpose of the Bankruptcy Abuse Prevention and Consumer Protection Act of 2003 is "to improve bankruptcy law and practice by restoring personal responsibility and integrity in the bankruptcy system and by ensuring that the system is fair for both debtors and creditors. ${ }^{32}$ The legislation attempts to accomplish this through a series of substantial modifications to the ways consumers and businesses can enter into and are treated by the bankruptcy system. ${ }^{33}$ Jacoby focused her comments on those portions of the 500-page piece of legislation that would affect unsecured creditors, including the means test, the disposable income calculation, and auto lender protections.

Jacoby began with an overview of one of the bill's most controversial provisions: a screen designed to keep certain debtors out of Chapter 7. The screen, she explained, is implemented by a "means test." ${ }^{\text {"4 }}$ The means test bars debtors from Chapter 7 if they meet either of the following criteria: They have the disposable income necessary to pay unsecured creditors

\footnotetext{
${ }^{30}$ Of the approximately $\$ 1.2$ billion returned to unsecured creditors through Chapters 7 and 13 in fiscal year 2001, Chapter 13 disbursements accounted for $\$ 805$ million. Flynn, supra note 11.

${ }^{31}$ For an overview of the literature that evaluates the rationale for reforming the bankruptcy system and the effectiveness of proposed changes, see Loretta Mester, Is the Personal Bankruptcy System Bankrupt? Bus. REV. 31 (Fed. Reserve Bank of Phila.) Mar. 2002, at http://www.phil.frb.org/files/br/brq102lm.pdf.

${ }^{32}$ H.R. REP. No. 108-40, at 121 (2003).

${ }^{33}$ For a brief overview of the proposed changes, see Angie A. Welborn, Bankruptcy Reform in the $108^{\text {th }}$ Congress, Congressional Research Service Report for Congress, May 12, 2003, at http://www.house.gov/burton/pdf/RL31783.pdf.

${ }^{34}$ For an economic analysis of the proposed means test and the extent to which the tightening of bankruptcy laws improves social welfare, see Wenli Li \& Pierre-Daniel Sarte, The Macroeconomics of U.S. Consumer Bankruptcy Choice: Chapter 7 or Chapter 13? Fed. Reserve Bank of Phila. Working Paper No. 03-14, September 2002, at http://www.phil.frb.org/files/wps/2003/wp03-14.pdf.
} 
$\$ 10,000$ or more in a Chapter 13 plan or they have sufficient disposable income to pay back at least a quarter of their debt under a Chapter 13 plan (if that quarter is at least $\$ 6,000$ ).

By limiting those who can seek protection under Chapter 7 and likely forcing a higher percentage of filers into Chapter 13, unsecured creditors hope to increase their chances of getting repaid. In Jacoby's opinion, however, this means test does not accurately evaluate repayment ability and other provisions of the new legislation may offset many of the advantages gained by Chapter 7 screening.

The means test, Jacoby explained, has a number of "safe harbors" that preclude Chapter 7 filers from being challenged under the means test. One of these safe harbors is for debtors whose monthly income is equal to or less than the median household income of their state. ${ }^{35}$ Henry E. Hildebrand III, chairman of the Legal and Legislative Rules Committee of the National Association of Chapter 13 Trustees, estimates that 84 percent of existing filers have household incomes below their state's median. ${ }^{36}$ This suggests that, on the basis of income alone, the screen would actually affect very few debtors. Jacoby explained that the means test does not apply to filers whose debts are not primarily consumer debts, allowing those with business- or investmentrelated debts to bypass the screen. High-income debtors can also shield themselves from being means tested out of Chapter 7 by taking on more secured debt. Professor Michael Staten of the Georgetown Credit Research Center estimates that, given these exceptions, fewer than 5 percent of bankruptcy filers will be funneled from Chapter 7 to Chapter 13 by the screen. ${ }^{37}$

Jacoby suggested that modifications to the disposable income calculations, which also would be used for Chapter 13 repayment plans, may also negatively impact unsecured creditors. Under the proposed legislation, disposable income will be calculated by subtracting the living

\footnotetext{
${ }^{35}$ Despite this safe harbor, Jacoby explained, low-income debtors would still need to file the means test paperwork.

${ }^{36}$ Linda Punch, Bankruptcy Reform: Try, Try Again, CRediT CARD MGMT., February 27, 2003, at 32.

${ }^{37}$ H.R. REP. NO. 108-40, at 563. But see United States General Accounting Office, GAO/GGD-98-47, Personal Bankruptcy: The Credit Research Center Report on Debtors' Ability to Pay (1998) (noting areas of concern with the Center report that could affect its conclusions).
} 
expenses, based on the Internal Revenue Service's National Standards for Allowable Living Expenses, from the debtor's income. Used by the IRS to calculate living expenses for those who evade their taxes, the standards would allow debtors with higher monthly incomes to spend more on clothing, food, and personal services than debtors with lower incomes. For example, under the current standards, a family of four with a household income of $\$ 28,000$ a year would be allowed $\$ 900$ in monthly living expenses, while the same family earning $\$ 70,000$ a year in income would be allowed $\$ 1,500$ per month. ${ }^{38}$ Although Jacoby did not speculate how this change would impact unsecured creditors, the extent to which the new standards could reduce disposable income would directly affect the monies available for creditor distribution.

Jacoby also asserts that the proposed legislation provides automobile lenders with greater protections at the expense of unsecured creditors. Under current Chapter 13 provisions, if a borrower has an $\$ 8,000$ loan on a car that has a market value of $\$ 6,000$, the automobile lender's claim is split (or "bifurcated"). As a result, the lender has a "secured" claim of $\$ 6,000$ and an "unsecured" claim of $\$ 2,000$. The $\$ 6,000$ obligation must be paid in full, with interest. In the plan, this debt would likely be among the first to be paid. The automobile lender's $\$ 2,000$ portion is unsecured, and as such, the lender receives only a pro-rata share of any remaining disposable income (just as any other unsecured creditor would). The new legislation does not permit bifurcation in most cases. ${ }^{39}$ Instead, the automobile lender in the example above would have a fully secured $\$ 8,000$ claim. This modification negatively affects unsecured lenders by increasing the size of the claims that have repayment priority.

Jacoby also discussed other changes that could affect unsecured creditors. Through Truth in Lending Act amendments, the new legislation requires enhanced unsecured loan disclosures.

\footnotetext{
${ }^{38}$ See Internal Revenue Service National Standards for Allowable Living Expenses, at http://www.irs.gov/businesses/small/article/0,,id=104627,00.html.

${ }^{39}$ See Bankruptcy Abuse Prevention and Consumer Protection Act of 2003, H.R. 975, 108th Cong. §306 (2003) (describing amendment to bankruptcy code that would eliminate bifurcation of automobile loans).
} 
These include minimum payment, late payment, and "teaser rate" warnings. ${ }^{40}$ The bill requires credit counseling as a condition of eligibility and financial education as a condition of discharge. Proponents hope such counseling will inform people about the alternatives to and consequences of bankruptcy. ${ }^{41}$ The legislation also requires that more plans last five years instead of three and make non-dischargeable debts for luxury goods acquired just prior to filing.

Overall, Jacoby does not believe that unsecured creditors will fare much better once inside the proposed system. In her view, the Chapter 7 screening mechanism will have little impact on changing the mix of consumer filings. Even if more people get funneled into Chapter 13, she believes that proposed modifications to that chapter could leave unsecured creditors worse off. The most obvious benefit for unsecured creditors, Jacoby asserted, is that some debtors could be delayed or deterred by the many new filing requirements and changes. This could give card issuers and other unsecured creditors more time to collect on their debts. In addition, less debt may be discharged in the bankruptcy process for those who file.

\section{Conclusion}

Although bankruptcy reform efforts have been under way for almost a decade, Jacoby remained doubtful that the proposed legislation will make positive improvements to the system or increase creditor returns in bankruptcy. In her opinion, the proposed system employs too many resources, has unclear goals, and may not provide any real benefits to unsecured creditors. Credit card issuers' losses, however, are mounting. Under the current system, it is expected that bankruptcies will cumulatively account for more than $\$ 60$ billion in charged-off credit card loans over the next three years. ${ }^{42}$ Card industry observers believe that even if just 10 percent of Chapter 7 filers can be funneled into Chapter 13, industry savings could be in the hundreds of millions of

\footnotetext{
${ }^{40}$ Welborn, supra note 33, at 10.

${ }^{41}$ Bankruptcy Bill Passes House and Heads to Senate, CARD NEWs, Apr. 2, 2003.

${ }^{42}$ Bankruptcy Losses on Cards, NILSON REP., Jan. 2003, at 6.
} 
dollars. ${ }^{43}$ Although this may be possible in theory, Jacoby and others doubt that the savings will be as significant because of the details of this legislation and the financial situations of the households that file.

${ }^{43} I d$. 